\title{
PENGEMBANGAN MEDIA DESTINASI PARIWISATA: MEMANFAATKAN POTENSI DAN SUMBER DAYA LOKAL DI ERA OTONOMI DAN PEMEKARAN DAERAH
}

\author{
Yosafati Hulu \\ Information Systems Department, School of Information Systems, Binus University \\ Jln. K.H. Syahdan No. 9, Palmerah, Jakarta Barat 11480 \\ yosahulu@yahoo.com
}

\begin{abstract}
Concerning about: (1) an increase in regional demand (government and community) in developing tourism destinations in the era of autonomy and separation, (2) the needs of tourists to choose the right attraction in accordance with their respective criteria, and (3) the needs of employers to offer sights of interest in accordance with the needs of potential tourists, a media is needed to be developed that can facilitate those needs. It is a web-based software system that can store and show tourist destinations of Indonesia in a comprehensive, systematic, and structured way. Besides, it can classify the various attractions based on attributes, such as: location (name of the island, province, district), tourism type/product, how to go to those objects, cost, and also another variety of informal information, such as: the ins and outs of the attraction area posted by the local community or travel experiences posted by tourists. The first phase will focus on a database system that enables local governments and local communities retain information attractions and products systematically and structurally so that potential tourists can find them easily through a simple search method. The database system is then a basis og other information that will be built on further research needs such as: Data Warehouse System, Decision Support System, and Expert System for Indonesia's tourism industry.
\end{abstract}

Keywords: media, tourism, database, destination, regional

\begin{abstract}
ABSTRAK
Mengingat adanya: (1) peningkatan kebutuhan daerah (pemerintah dan masyarakat) dalam mengembangkan destinasi pariwisata di era otonomi dan pemekaran, (2) kebutuhan wisatawan untuk memilih dengan tepat objek wisata sesuai dengan kriterianya masing-masing, dan (3) kebutuhan pengusaha untuk menawarkan objek-objek wisata yang menarik sesuai dengan kebutuhan calon wisatawan, perlu dikembangkan suatu media yang mampu memfasilitasi kebutuhan-kebutuhan tersebut. Media ini berupa sistem perangkat lunak berbasis web yang mampu menyimpan dan menyajikan destinasi pariwisata Indonesia secara menyeluruh, sistematis, dan terstruktur. Selain itu, bisa mengklasifikasikan berbagai objek wisata berdasarkan atribut, seperti: lokasi (nama pulau, propinsi, kabupaten), jenis/produk wisata, bagaimana mencapai objek tersebut, biaya, dan juga berbagai informasi informal, seperti: seluk beluk objek wisata daerah yang dimasukkan oleh masyarakat lokal atau berbagai pengalaman wisata yang dimasukan oleh wisatawan. Tahap pertama akan fokus pada sistem database yang memampukan pemerintah daerah dan masyarakat lokal menyimpan informasi objekobjek wisata dan produknya secara sistematis dan terstruktur sehingga calon wisatawan dapat menemukannya dengan mudah melalui metode pencarian sederhana. Sistem Database inilah yang kemudian menjadi landasan informasi lain yang akan dibangun pada penelitian-penelitian selanjutnya untuk kebutuhan seperti: Data Warehouse System, Decision Support System, dan Expert System bagi industri pariwisata Indonesia.
\end{abstract}

Kata kunci: media, wisata, database, destinasi, daerah 


\section{PENDAHULUAN}

Pertumbuhan Destinasi Pariwisata di Indonesia di era otonomi dan pemekaran daerah cukup tinggi dibandingkan dengan era sebelumnya. Masing-masing daerah otonom atau daerah pemerintahan baru hasil pemekaran berupaya mencari dan mengembangkan potensi wisata di wilayahnya supaya bisa dijual untuk menambah PAD (Pendapatan Asli Daerah) dan meningkatkan ekonomi masyarakatnya.

Upaya tersebut tentu akan berhasil bila didukung oleh suatu media yang mempermudah penyajian destinasi pariwisata beserta produknya kepada calon-calon wisatawan. Tanpa media yang lengkap dan terintegrasi akan membuat calon wisatawan atau pengusaha yang bergerak dalam industri pariwisata sulit mengetahui dan mengenal dengan lengkap destinasi pariwisata baru yang tadinya belum dikenal atau destinasi pariwisata lama tapi aktifitas dan produknya baru dikembangkan.

Mengingat hal tersebut, perlu dibangun dan dikembangkan suatu media yang mendukung (sekaligus menjembatani) kebutuhan daerah untuk menyajikan dan mempromosikan objek wisata beserta produk-produknya dan kebutuhan wisatawan dan kalangan pengusaha untuk menemukan dengan mudah objek wisata yang diinginkan di antara ribuan objek wisata yang tersebar di wilayah Indonesia (Lihat Gambar 1).

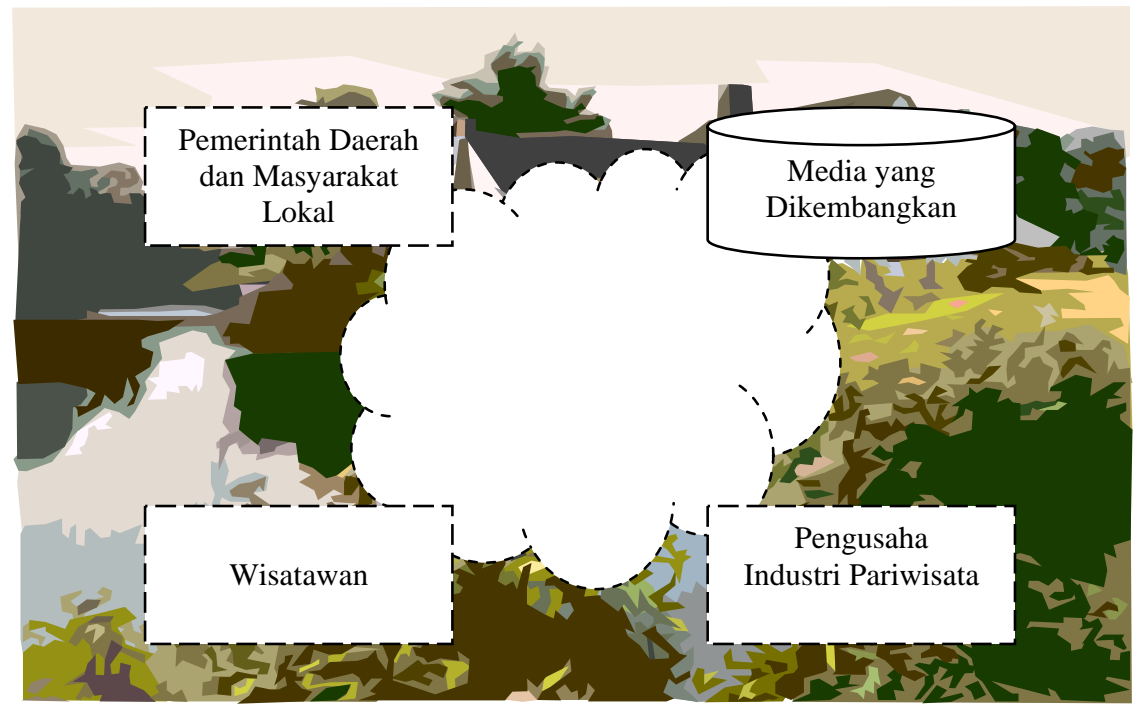

Gambar 1. Media yang akan dikembangkan.

Penelitian dilakukan karena: (1) ada peningkatan kebutuhan daerah (pemerintah dan masyarakat) untuk mengembangkan destinasi pariwisata di era otonomi dan pemekaran dibandingkan di era sebelumnya; (2) ada kebutuhan masyarakat (wisatawan) untuk memilih dengan tepat objek wisata sesuai dengan kriterianya masing-masing; (3) ada kebutuhan pengusaha travel/hotel untuk menawarkan objek-objek wisata yang menarik sesuai dengan kebutuhan calon wisatawan, sementara media yang memfasilitasi kebutuhan-kebutuhan tersebut belum ada.

Media ini mampu menyimpan dan menyajikan destinasi pariwisata secara menyeluruh, sistematis, dan terstruktur serta bisa mengklasifikasikan berbagai objek wisata berdasarkan atribut seperti: lokasi (nama pulau, propinsi, kabupaten), jenis/produk wisata, bagaimana mencapai objek tersebut, biaya, dan juga berbagai informasi informal seperti: seluk beluk objek wisata daerah yang 
dimasukkan oleh masyarakat lokal atau berbagai pengalaman wisata yang dimasukan oleh wisatawan. Bila hal ini berhasil dikembangkan maka ini bisa menjadi titik awal munculnya penelitian lanjutan dalam membangun suatu media lengkap sehingga bisa digunakan sebagai, antara lain, Data Warehouse System, Decision Support System, dan Expert System bagi industri pariwisata Indonesia.

Perlu juga dijelaskan bahwa dari hasil analisis awal dari berbagai studi literatur, seperti: jurnal, artikel, dan website atau portal pariwisata di internet, dapat diuraikan sebagai berikut: (1) belum ada media yang terintegrasi tentang destinasi pariwisata di Indonesia secara menyeluruh, yang ada baru per daerah atau per objek wisata; (2) belum ada media yang memungkinkan secara langsung melibatkan potensi dan sumber daya lokal dalam memasukkan berbagai informasi objek wisata di wilayahnya sendiri. Padahal “... pentingnya keterlibatan warga dalam mengembangkan destinasi pariwisata” (Pangestu, 2011); (3) belum ada media yang memudahkan wisatawan mencari objek wisata di Indonesia berdasarkan atribut: lokasi (nama pulau, propinsi, kabupaten), jenis/produk wisata, bagaimana mencapai objek tersebut, biaya, dan juga berbagai informasi informal seperti: seluk beluk objek wisata daerah yang diinput oleh masyarakat lokal atau berbagai informasi pengalaman wisata yang diinput oleh wisatawan itu sendiri.

Kemudian, dari studi literatur, seperti: "Visi Pengembangan Destinasi Pariwisata Indonesia”, "Rencana Pengembangan Ekonomi Kreatif Indonesia 2009-2025”, "Rencana Strategis Kementrian Pariwisata dan Ekonomi Kreatif", "Pemanfaatan Teknologi Informasi dalam Promosi Destinasi Wisata", dan "Pengembangan Destinasi Wisata Harus Libatkan Warga", perlu dibangun suatu media yang lengkap dan terintegrasi serta fleksibel untuk dikembangkan lebih lanjut pada penelitianpenelitian berikutnya. Gambar 2 menunjukkan hasil studi pendahuluan yang telah dilakukan seperti yang telah dijelaskan sebelumnya.

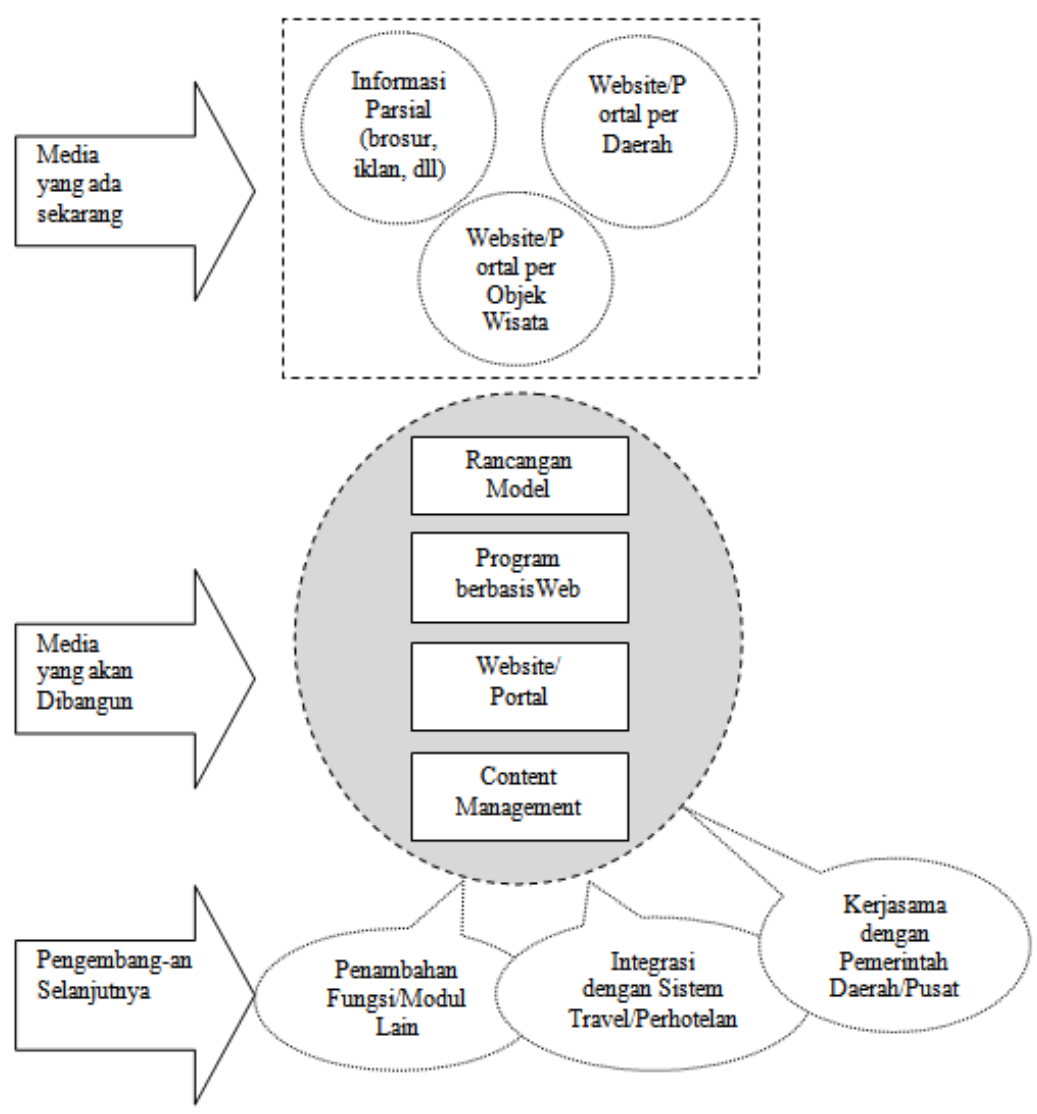

Gambar 2. Hasil Studi Pustaka 
Pada Gambar di atas, terlihat bahwa media yang akan dibangun adalah sistem perangkat lunak berbasis web yang dapat diakses secara luas melalui internet. Sistem ini mampu menyimpan dan menyajikan baik informasi formal maupun informal (seperti seluk beluk objek wisata daerah, yang dimasukkan oleh masyarakat lokal atau berbagai pengalaman wisata yang dimasukan oleh wisatawan itu sendiri).

Media ini akan dibangun dalam beberapa tahap dan dilakukan secara berkesinambungan sehingga menjadi media yang lengkap dan efektif dalam membantu pengembangan destinasi pariwisata di Indonesia. Ada tiga tujuan awal yang ingin dicapai dalam penelitian ini, yaitu: (1) adanya media yang mampu digunakan untuk merekam dan menyajikan seluruh destinasi pariwisata di Indonesia secara rinci; (2) adanya media yang mampu melibatkan langsung masyarakat lokal dalam menyajikan berbagai hal tentang destinasi pariwisata di daerahnya; (3) adanya media yang mampu menerima berbagai informasi tentang pengalaman wisatawan dalam mengunjungi objek wisata tertentu.

Jadi, penelitian ini akan fokus pada pembangunan Sistem Database Objek Wisata yang memampukan pemerintah daerah dan masyarakat lokal menyimpan objek-objek wisata dan produknya secara sistematis dan terstruktur sehingga calon wisatawan dapat menemukannya dengan mudah melalui metoda pencarian yang sederhana. Sistem Database inilah yang kemudian menjadi landasan awal pada penelitian-penelitian selanjutnya.

\section{METODE}

Metode penelitian "Pengembangan Media Destinasi Pariwisata Memanfaatkan Potensi dan Sumberdaya Lokal di Era Otonomi Dan Pemekaran Daerah” dilakukan secara bertahap seperti pada Gambar 3 di bawah ini.

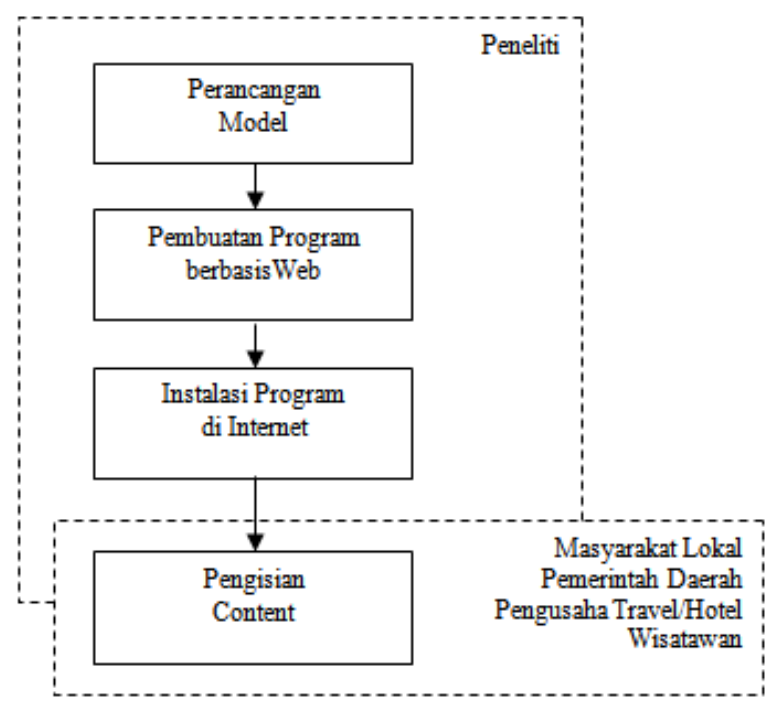

Gambar 3. Tahapan penelitian.

Gambar 3 membagi dua kelompok pekerjaan yaitu: (1) aktifitas yang dilakukan oleh peneliti dan (2) aktifitas yang dilakukan oleh pengguna (masyarakat lokal, pemerintah daerah, pengusaha travel/hotel, wisatawan, dan lain-lain). Masing-masing tahapan diuraikan berikut ini. 


\section{Perancangan Model}

Pada tahap ini akan dirancang model media yang tepat supaya bisa menyimpan, menyajikan, dan mencari informasi objek wisata di seluruh Indonesia. Atribut objek wisata akan dipelajari lewat jurnal, buku, atau informasi di internet (website yang berkaitan dengan objek wisata) kemudian atribut tersebut dirumuskan untuk menghasilkan model database yang mengakomodasi seluruh informasi yang diperlukan.

Media ini juga dibangun supaya mampu menerima informasi dari berbagai kalangan berdasarkan hak otoritas yang diberikan. Oleh karena itu, User Interface, Verifikasi Informasi, dan Struktur Menu dirancang sedemikian rupa sehingga penempatan informasi oleh pengguna dapat diarahkan sesuai dengan struktur, klasifikasi, dan atribut objek-objek wisata. Rancangan model dapat dilihat pada Gambar 4.

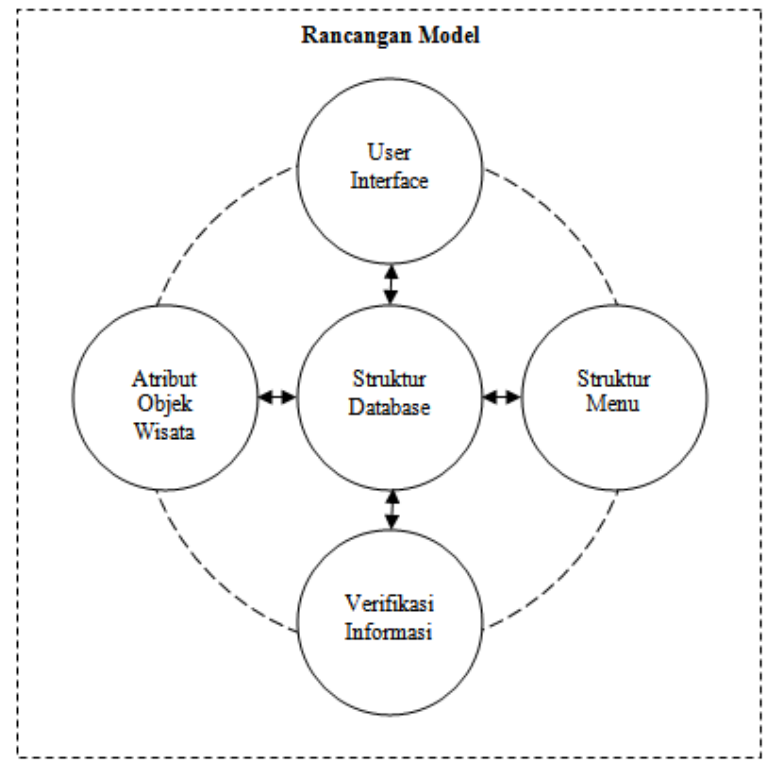

Gambar 4. Rancangan model.

\section{Pembuatan Program berbasis Web}

Program Aplikasi yang akan dibuat harus menghasilkan sistem yang mudah digunakan oleh berbagai kalangan. Oleh karen itu program harus memenuhi: (1) bahasa pemrogram dan database yang dipergunakan dalam pembuatan media ini harus berbasis web supaya bisa diimplentasikan di internet sehingga mudah diakses secara luas oleh setiap pengguna; (2) user interface merupakan satu hal yang paling utama diperhatikan sehingga masyarakat lokal bisa memasukan dengan mudah berbagai informasi yang berhubungan dengan objek wisata di daerahnya dan sebaliknya calon wisatawan bisa mencari dengan mudah objek wisata yang dibutuhkannya dengan memasukan atau memilih dari berbagai atribut. Program Aplikasi yang dibuat harus diuji coba dulu di server lokal untuk menghilangkan atau memperkecil kesalahan-kesalahan atau bug yang mungkin terjadi setelah diterapkan atau di-instal jaringan yang lebih luas (internet).

\section{Instalasi Program di Internet}

Penerapan program aplikasi diawali dengan mendaftarkan nama domain yang singkat, mudah ditulis, dieja, dan didengar, serta menggambarkan informasi tentang destinasi pariwisata di Indonesia. Selanjutnya melakukan penyewaan server (hosting) kepada pihak ketiga atau operator yang handal dan 
bisa dipercaya dengan harga sewa yang ekonomis. Konfigurasi server yang diperlukan juga disesuaikan dengan kebutuhan untuk satu tahun karena bisa diperpanjang untuk tahun-tahun selanjutnya (penyewaan secara bertahap).

Setelah pendaftaran nama domain dan penyewaan server dilakukan, program aplikasi yang telah selesai dibuat akan diinstal di server yang telah disewa supaya sistem bisa aktif dan siap digunakan oleh semua kalangan pengguna berdasarkan hak otoritas yang telah ditentukan.

\section{Pengisian Content}

Setelah penerapan program aplikasi di internet, secara praktis media ini telah berfungsi dan siap digunakan. Pengisian contoh informasi beberapa objek wisata akan dilakukan dalam penelitian ini sedangkan pengisian informasi yang lengkap dilakukan secara bertahap dan berkesinambungan oleh: masyarakat lokal, pemerintah daerah, pengusaha travel/hotel, dan wisatawan.

\section{HASIL DAN PEMBAHASAN}

Hasil penelitian yang dilakukan khususnya atribut objek wisata, rancangan database, dan verifikasi informasi akan diuraikan berikut ini. Hal ini merupakan sebagian dari hasil penelitian yang dilakukan berdasarkan rancangan model yang telah dijelaskan pada Gambar 4 sebelumnya.

\section{Atribut Objek Wisata}

Informasi objek wisata dapat dibagi dua, yaitu: informasi utama dan informasi tambahan. informasi utama adalah informasi yang menjelaskan tentang objek wisata itu sendiri sedangkan informasi tambahan adalah informasi yang relevan dengan objek wisata tersebut dan dapat dimasukkan oleh setiap user.

Atribut utama dapat dilihat pada Tabel 1. Atribut ini bisa berkembang disesuikan dengan kebutuhan setelah tahap implementasi.

Tabel 1

Atribut Objek Wisata

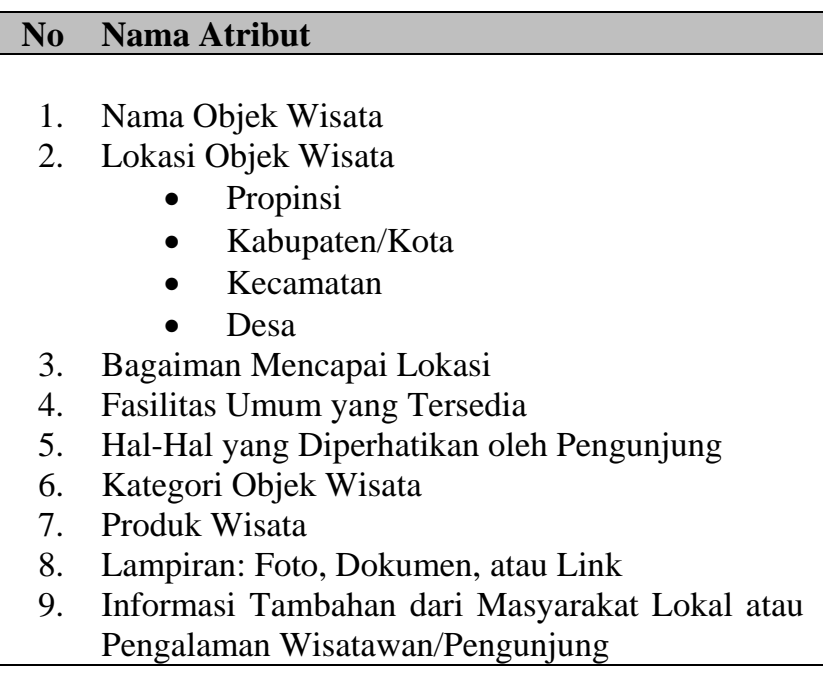




\section{Rancangan Database}

Struktur tabel-tabel utama yang digunakan dapat dilihat pada Tabel $2-11$ berikut. Strukur ini merupakan hasil akhir dari proses optimalisasi yang dilakukan berdasarkan atribut utama objek wisata yang telah ditentukan pada pembahasan sebelumnya. Jenis Field (Field Type) akan disesuaikan dengan sintaks MySql sebagai database yang akan digunakan dalam pembuatan media ini.

Tabel 2

Tabel Objek Wisata

\begin{tabular}{cllll}
\hline No & Nama Field & Jenis & M/O & Keterangan Singkat \\
\hline 1. & OW_KODE & CHAR (8) & M & Kode Objek Wisata \\
2. & OW_NAMA & VARCHAR (80) & M & Nama Objek Wisata \\
3. & OW_NAMA_LL & VARCHAR (80) & O & Nama Lain / Populer dari Objek Wisata \\
4. & PRO_KODE & CHAR(2) & M & Lokasi Objek Wisata (Kode Propinsi) \\
5. & KAB_KODE & CHAR(4) & M & Lokasi Objek Wisata (Kode Kabupaten/Kota) \\
6. & KEC_KODE & CHAR(8) & M & Lokasi Objek Wisata (Kode Kecamatan) \\
7. & DES_KODE & CHAR(8) & M & Lokasi Objek Wisata (Kode Desa) \\
8. & CARA_MENCAPAI & TEXT & M & Bagaiman mencapai lokasi Objek Wisata \\
9. & FASILITAS & TEXT & M & Fasilitas umum yang tersedia \\
10. & HAL_PERHATIAN & TEXT & M & Hal-hal yang perlu diperhatikan \\
11. & STATUS & CHAR(1) & M & Status (N: Belum diotorisasi, Y: Sudah \\
& & & diverifikasi) & \\
\hline
\end{tabular}

Tabel ini adalah tabel utama yang menyimpan informasi utama tentang objek-objek wisata atau destinasi pariwisata.

Tabel 3

OW_OW (Tabel Hubungan Objek Wisata dengan Objek Wisata Lain)

\begin{tabular}{|c|c|c|c|c|}
\hline No & Nama Field & Jenis & $\mathbf{M} / \mathbf{O}$ & Keterangan Singkat \\
\hline 1. & OW_KODE & CHAR (8) & M & Kode Objek Wisata \\
\hline 2. & OW_KODE_DKT & CHAR (8) & M & Objek Wisata yang berdekatan \\
\hline 3. & JARAK_KM & MEDIUMINT & M & Jarak (KM) antara objek wisata terdekat \\
\hline 4. & WAKTŪ_TEMPUH & & M & $\begin{array}{l}\text { Waktu Tempuh (Jam:Menit) antara objek wisata } \\
\text { terdekat }\end{array}$ \\
\hline 5. & WAKTU_TEMPUH_DGN & CHAR(1) & $\mathrm{M}$ & $\begin{array}{l}\text { Waktu Tempuh dengan apa? Mis: Pesawat, Kereta } \\
\text { Api, Mobil, Sepeda Motor, atau Jalan Kaki }\end{array}$ \\
\hline 6. & STATUS & CHAR(1) & M & $\begin{array}{l}\text { Status (N: Belum diotorisasi, Y: Sudah } \\
\text { diverifikasi) }\end{array}$ \\
\hline
\end{tabular}

Tabel yang menghubungkan antara objek wisata dengan objek wisata yang lain. Tabel ini berguna bagi calon wisatawan untuk mengetahui objek wisata apa saja yang berdekatan dengan objek wisata tertentu sehingga bisa digunakan sebagai referensi atau bantuan dalam memutuskan apakah mau mengunjungi lokasi-lokasi tersebut secara bersamaan atau tidak.

Tabel 4

KATEGORI (Kategori Objek Wisata)

\begin{tabular}{clllll}
\hline No & Nama Field & Jenis & M/O & Keterangan Singkat & \\
\hline & & & & & \\
1. & KATEGORI_KODE & CHAR (2) & M & Kode Kategori Objek Wisata & \\
2. & KATEGORI_NAMA & VARCHAR (20) & M & Nama Kategori Objek Wisata & \\
3. & STATUS & CHAR(1) & M & $\begin{array}{l}\text { Status (N: Belum diverifikasi, Y: Sudah } \\
\text { diverifikasi) }\end{array}$ \\
\hline
\end{tabular}

Tabel yang menyimpan daftar kategori objek wisata. 
Tabel 5

OW_KATEGORI (Objek Wisata dan Kategorinya)

\begin{tabular}{|c|c|c|c|c|c|c|}
\hline No & Nama Field & Jenis & $\mathbf{M} / \mathbf{O}$ & Keterangan Singkat & & \\
\hline 1. & OW_KODE & CHAR (8) & M & Kode Objek Wisata & & \\
\hline 2. & KATEGORI_KODE & CHAR (2) & M & Kode Kategori Objek Wisata & & \\
\hline 3. & KETERANGAN & TINYTEXT & $\mathrm{O}$ & Keterangan Tambahan kalau ada & & \\
\hline 4. & STATUS & CHAR(1) & M & $\begin{array}{l}\text { Status (N: Belum diverifikasi, } \\
\text { diverifikasi) }\end{array}$ & Y: & Sudah \\
\hline
\end{tabular}

Tabel yang menyimpan kategori objek wisata. Dengan adanya tabel ini maka objek wisata dapat dikelompokkan dalam beberapa kategori sehingga memudahkan dalam perekaman dan penyajian objek wisata.

Tabel 6

PRODUK (Objek Wisata dan Produknya)

\begin{tabular}{llllll}
\hline No & Nama Field & Jenis & M/O & Keterangan Singkat & \\
\hline & & & & & \\
1. & PRODUK_KODE & CHAR (4) & M & Kode Produk Wisata & \\
2. & PRODUK_NAMA & TINYTEXT & M & Nama Produk Wisata & \\
3. & STATUS & CHAR(1) & M & $\begin{array}{l}\text { Status (N: Belum diverifikasi, Y: Sudah } \\
\text { diverifikasi) }\end{array}$ \\
\hline
\end{tabular}

Tabel yang menyimpan daftar produk objek wisata.

Tabel 7

OW_PRODUK (Objek Wisata dan Kategorinya)

\begin{tabular}{|c|c|c|c|c|c|c|}
\hline No & Nama Field & Jenis & $\mathbf{M} / \mathbf{O}$ & Keterangan Singkat & & \\
\hline 1. & OW_KODE & CHAR (8) & M & Kode Objek Wisata & & \\
\hline 2. & PRODUK_KODE & CHAR (4) & M & Kode Produk Wisata & & \\
\hline 3. & KETERANGAN & TINYTEXT & $\mathrm{O}$ & Keterangan Tambahan kalau ada & & \\
\hline 4. & STATUS & CHAR(1) & M & $\begin{array}{l}\text { Status (N: Belum diverifikasi, } \\
\text { diverifikasi) }\end{array}$ & Y: & Sudah \\
\hline
\end{tabular}

Tabel yang menyimpan produk apa saja yang ada pada objek wisata tertentu. Dengan adanya tabel ini maka objek wisata dapat memiliki beberapa produk objek wisata sehingga memudahkan dalam perekaman dan penyajian objek wisata.

Tabel 8

LAMP (Lampiran atau Attachment)

\begin{tabular}{cllcl}
\hline No & Nama Field & Jenis & M/O & Keterangan Singkat \\
\hline 1. & LAMP_CODE & CHAR (8) & M & Kode Lampiran \\
2. & LAMP_ALM & TINYTEXT & M & Alamat Lampiran disimpan \\
3. & LAMP_JNS & CHAR(1) & M & Jenis Lampiran: Foto, Dokumen, atau Link \\
4. & LAMP_WKT & DATETIME & M & Waktu Lampiran di-attach atau waktu upload \\
5. & SUMBER & TINYTEXT & M & Sumber Lampiran \\
6. & STATUS & CHAR(1) & M & Status (N: Belum diverifikasi, Y: Sudah \\
& & & diverifikasi) \\
\hline
\end{tabular}

Tabel Lampiran berguna untuk menyimpan alamat lampiran (foto, dokumen, dan link) disimpan (di-attach). Tabel ini bisa digunakan oleh tabel-tabel lain dengan mengaitkannya dengan field LAMP_CODE. 
Tabel 9

OW_LAMP (Lampiran Objek Wisata)

\begin{tabular}{lllll}
\hline No & Nama Field & Jenis & M/O & Keterangan Singkat \\
\hline & & & & \\
1. & OW_KODE & CHAR (8) & M & Kode Objek Wisata \\
2. & LAMP_CODE & CHAR (8) & M & Kode Lampiran \\
\hline
\end{tabular}

Tabel ini merupakan relasi antara Tabel $\mathbf{O W}$ dengan Tabel LAMP. Dengan adanya tabel ini maka informasi utama tentang objek wisata bisa disertai dengan foto, dokumen, dan link sebagai pendukung informasi utama.

Tabel 10

INFO (Informasti Tambahan Objek Wisata)

\begin{tabular}{cllll}
\hline No & Nama Field & Jenis & M/O & Keterangan Singkat \\
\hline & & CHAR (8) & M & Kode Objek Wisata \\
1. & OW KODE & CHAR (8) & M & Kode Informasi Tambahan \\
2. & INFO_KODE & TEXT & M & Informasi yang dimasukkan \\
3. & INFO_NARASI & DATETIME & M & Waktu info diinput atau waktu upload \\
4. & INFO_WAKTU & TINYTEXT & M & Sumber Informasi Tambahan \\
5. & INFO_SUMBER & CHAR(1) & M & Status (N: Belum diverifikasi, Y: Sudah \\
6. & STATUS & & diverifikasi) \\
& & &
\end{tabular}

Tabel di atas berisi informasi yang relevan dengan objek wisata dan bisa dimasukkan oleh setiap orang yang terlibat. Misalnya informasi tambahan yang dimasukkan oleh masyarakat lokal tentang objek wisata di daerahnya atau informasi tentang pengalaman wisatawan yang terkait dengan objek wisata yang bersangkutan.

Tabel 11

INFO_LAMP (Informasti Tambahan Objek Wisata)

\begin{tabular}{cllll}
\hline No & Nama Field & Jenis & M/O & Keterangan Singkat \\
\hline & & & & \\
1. & OW_KODE & CHAR (8) & M & Kode Objek Wisata \\
2. & INFO KODE & CHAR (8) & M & Kode Informasi Tambahan \\
3. & LAMP_CODE & CHAR (8) & M & Kode Lampiran \\
\hline
\end{tabular}

Tabel relasi antara Tabel INFO dengan Tabel LAMP. Dengan adanya tabel ini maka informasi tambahan bisa disertai dengan foto, dokumen, dan link sebagai pendukung informasi tambahan.

\section{Verifikasi Informasi}

Salah satu kelebihan media ini adalah sifatnya yang terbuka. Artinya, setiap orang bisa berkonstribusi langsung dalam menambah informasi objek wisata sehingga sumber informasi tidak terbatas dan informasi yang relevan bisa didapatkan secara luas. Namun, masalah akan timbul bila informasi yang dimasukkan tidak akurat atau tidak valid. Oleh karena itu, verifikasi informasi (Gambar 5) merupakan hal yang wajib dilakukan dengan cara: (1) menambah satu field status di setiap tabel penyimpanan data atau informasi sehingga bisa membedakan antara informasi yang telah diverifikasi dengan yang belum diverifikasi; (2) mengelompokkan user dengan beberapa kategori, misalnya: User Umum, User Moderator, dan User Admin; (3) User Admin atau User Moderator diberi hak untuk melakukan verifikasi terhadap informasi yang dimasukkan oleh User Umum. 


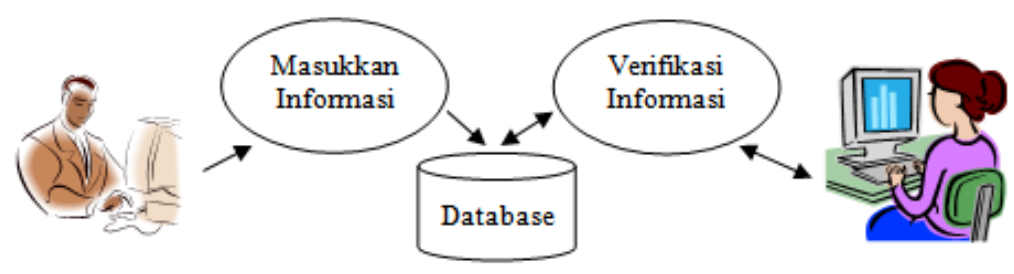

Gambar 5. Proses verifikasi informasi.

\section{PENUTUP}

Media destinasi pariwisata yang dibangun berguna untuk: merekam dan menyajikan seluruh destinasi pariwisata di Indonesia secara rinci, mendorong keterlibatan masyarakat lokal dalam menyajikan berbagai hal tentang destinasi pariwisata di daerahnya, dan merekam berbagai pengalaman wisatawan dalam mengunjungi objek wisata tertentu. Jika informasi yang dimasukkan telah lengkap maka media ini akan menjadi sistem informasi objek wisata yang terintegrasi untuk seluruh wilayah Indonesia.

Media ini bersifat terbuka. Karena itu, setiap user dapat berkonstribusi dalam memasukkan informasi yang relevan dengan objek wisata tertentu. Keakuratan dan Keabsahan informasi akan dijaga atau dijamin dengan memberikan fasilitas verifikasi bagi admin atau moderator.

Pengelompokan informasi dalam media ini dilakukan berdasarkan: (1) struktur pemerintahan mulai dari provinsi sampai dengan desa; (2) kategori objek wisata; (3) kedekatan antar lokasi. Pengelompokan ini menjadi penting karena memberikan kemudahan dan keleluasan bagi user untuk menyimpan, menyajikan, dan mencari objek wisata yang diinginkan.

Sistem ini juga menjadi landasan dalam pembangunan Data Warehouse System, Decision Support System, dan Expert System bagi industri pariwisata Indonesia.

\section{DAFTAR PUSTAKA}

Kementrian Pariwisata dan Ekonomi Kreatif. (2010). Rencana Strategis Kementrian Pariwisata dan Ekonomi Kreatif. Jakarta: Kementrian Pariwisata dan Ekonomi Kreatif.

Pangestu, Mari Elka. (2008). Pengembangan ekonomi kreatif indonesia 2025. Disampaikan dalam Konvensi Pengembangan Ekonomi Kreatif 2009-2015 yang diselenggarakan pada Pekan Produk Budaya Indonesia 2008, JCC, 4-8 Juni 2008.

Pangestu, Mari Elka. (2011). Pengembangan Destinasi Wisata Harus Libatkan Warga. Jakarta: Kompas. 